\title{
Study of the aging of fermented of yacon (Smallanthus sonchifolius) and sensory profile and acceptance
} Camila Cheker BRANDÃO ${ }^{1 \star}$, Eduardo Ramirez ASQUIERI ${ }^{1}$, Shireen ATTARAN ${ }^{2}$, Clarissa DAMIANI ${ }^{1}$

\begin{abstract}
Yacon is considered a functional food due to its the fructooligosaccharide (FOS) content, however its perishability and low production volume is a problem. The aim of this study was to analyze the changes in aging during one year of storage and conduct sensory analysis of fermented of yacon. For one year total acidity, volatile acidity, free and total sulfur dioxide, reducing sugars, sucrose, phenols and FOS and its antioxidant power were studied. At the end of aging a sensory profile and acceptance panel was performed. The total and volatile acidity increased significantly $(\mathrm{p}<0.05)$. A decrease in fructooligosaccharide was also observed, indicating that yeasts are probably capable of hydrolyzing the latter. The total sulfur dioxide decreased significantly, demonstrating its ability to act well against oxidation products. This product showed good antioxidant capacity and sensory profiles of considerable acceptance. Therefore it can be affirmed that the alcoholic fermentation of yacon can be a good alternative for the industrial sector and farmers in the region could be encouraged to use large-scale production.
\end{abstract}

Keywords: alcoholic beverage; fermented fruit; fructooligosaccharide; antioxidant capacity.

\section{Introduction}

Yacon, originating in the Andes, is a tuberous root that stores fructooligosaccharides (FOS). A key property of FOS is that these sugars are not digested by the human body, the body is not capable of producing enzymes to hydrolyze this sugar, and therefore it is classified as a dietary fiber or as soluble fiber (Ojansivu et al., 2011).

Despite its pleasant fruity flavor, production in Brazil is low and consumers lack a great deal of information regarding this food. Other fruits which have undergone fermented alcoholic technologies, with the aim of promoting increased production are cacao (Dias et al., 2007), gabiroba (Duarte et al., 2009), cupuaçu (Duarte et al., 2010), litchi (Wu et al., 2011) cagaita (Oliveira et al., 2011).

The production of fermented alcohol is very promising. The best known is the wine that comes from fermented grape, which is considered one of the oldest drinks in the world and part of the culture of different countries. Its complex aroma, from the dynamic process of fermentation generates fascination among researchers, resulting in numerous studies (Wu et al., 2011; Fanzone et al., 2012).

The chemical complexity of this product is wide ranging with the aromatic compounds being derived from a raw material through the fermentation process or through the metabolism of the yeast. There are many variables which can influence the chemical composition of the final product, such as, raw material and processing characteristics. Specifically these variables consist of soil, climate, temperature and $\mathrm{pH}$ of the fermentation process as well as the variety in yeast strain used (Soleas et al., 1997; Diäaz-Maroto et al., 2005; Meillon et al., 2009).
After the process of fermentation, it is a very common practice to allow the fermentate to age in a process called aging. Research must be conducted to see whether the fermentation or aging is unfavorable. During this phase, numerous variables influence the characteristics of the final product, for example, the type of positioning of the bottle closure, temperature, and ambient light, in addition to the natural chemical reactions which occur inside the cylinder with time (Rapp, 1998; Lopes et al., 2006; Recamales et al., 2011).

The process of fermenting fruit is old, but continues to draw attention by using unconventional raw material such as yacon tuber. The preparation of a fermented alcoholic would come against the problem of perishability of the tubers, as well as the demand for new products in the consumer market.

The present study is to investigate the behavior of the alcoholic fermentation of yacon. This was conducted during an aging duration of one year through evaluating physical chemistry, biochemistry, antioxidant capacity and sensory profile thereof.

\section{Materials and methods}

\subsection{Materials}

Yacon was purchased from the Central Supply Goiás (CEASA-GO). The fermentation process and aging was conducted at the Laboratory of Food Chemistry and Biochemistry, Faculty of Pharmacy, Federal University of Goiás and is protected on the patent No.BR 1020120052733.

${ }^{1}$ Faculty of Agronomy, Federal University of Goiás - UFG, Goiania, GO, Brazil, e-mail: camilacheker@yahoo.com.br

2 United States Department of Agriculture - USDA, Berkeley, California, USA

${ }^{*}$ Corresponding author 


\subsection{Methods}

\section{Chemical control}

After preparation, the product was placed in glass bottles, capped with screw caps and sealed with paraffin, placed horizontally at $15^{\circ} \mathrm{C}$ and stored for one year in an appropriate cellar without light for the respective aging.

Chemical analyses were performed every two months on the product and for one year. These analyses included (Latimer, 2006), total acidity, volatile acidity, free and total sulfur dioxide (Brasil, 1988), reducing sugars, modified sucrose (Miller, 1959), phenolic compounds according to the spectrophotometric method using the Folin-Ciocalteu 765nm range and standard curve as gallic acid (Zieliski \& Kozowska, 2000) and fructooligosaccharides (Jermyn, 1956).

After one year of aging, the alcohol content was evaluated (Brasil, 1988), as well as the content of methanol (Rizzon \& Miele, 2003). To measure ethyl carbamate (Brasil, 1988) and its respective antioxidant activity, the following methods were used:

DPPH (2,2-diphenyl-1-picryl-hydrazyl) - which is based on the capture of DPPH by antioxidant (Trolox), producing a decrease in absorbance at $515 \mathrm{~nm}$. The results were expressed in $\mathrm{mg}$ of Trolox/mL (Brand-Willians et al., 1995).

ABTS (3-ethylbenzothiazoline-6-sulfonic acid) - a method which applies to hydrophilic and lipophilic antioxidants. ABTS radicals are generated by oxidation of ABTS with potassium persulfate which is subsequently reduced in the presence of hydrogen donor by the antioxidant (Trolox). The results were expressed in mg of Trolox/mL (Rufino et al., 2007).

\section{Sensory profile - Trained tasters}

Sensory evaluation was performed following one year of storage, with ten qualified tasters in the sensory analysis of grape wine, with ages ranging from 38 to 60 and are members of the Association of Sommeliers Goiania. The attributes selected for analysis were those normally used by trained panelists.

The quantitative descriptive analysis was based on two structured scales, a six point and another four point (Figure 1). Fermentate analysis was conducted on yacon along with the usual rules and regulations of the testers. Two types of white wines that served as a standard by the trained group, Chardonnay and Sauvignon Blanc, were used. The choice of white wine was due to the resulting final color after one year of aging yacon fermentate.

The samples were served in standard glass cups for analysis of wine $(30 \mathrm{~mL})$ according to ISO 3591 (International Organization for Standardization, 1997), covered with glass to minimize the loss of volatile compounds and enumerated with random three digits numbers.

The location that was used for analysis adhered to the standards according to ISO 8589 (International Organization for Standardization, 1998), which recommend individual cabins with a room temperature of $18-21{ }^{\circ} \mathrm{C}$. These analyses were performed in order to obtain an indication of the influence of the new fermentation in relation to the perception and the intensity of each attribute (taste test). All the sensory analysis were conducted with the approval of the Research Ethics Committee of Federal University of Goiás with the protocol 009 /2012.

\section{Acceptance - Untrained sensory tasters}

For acceptance of the alcoholic fermentate, the tests were carried out with 100 untrained panelists in individual booths. The samples were presented in random order. Samples (fermented of yacon and white wine) with the same characteristics in sugar and alcohol content were presented at the temperature of $17^{\circ} \mathrm{C}$ and fermentate acceptance was assessed in relation to the attributes of appearance, aroma, flavor and their overall impression. Panelists recorded their notes on cards with 9-point hedonic scale for each attribute. Purchase intent of assessors was also analyzed. All the sensory analysis were conducted with the approval of the Research Ethics Committee of Federal University of Goiás with the protocol 009/2012

\section{Statistical analysis}

The evaluation of the influence of variables in relation to the time of fermentation was performed using the Friedman test for paired comparison and variable with respect to time using Wilcoxon test. The analysis for antioxidant activity (DPPH and ABTS) was performed using Pearson correlation. For the sensory analysis of trained tasters, analysis of variance - (ANOVA) and Tukey multiple comparisons were used. Student $t$ test was used for sensory analysis of acceptance (untrained tasters). All tests were applied with a significance level of $\mathrm{p}<0.05$.

\section{Results}

\subsection{Chemical monitoring during the aging}

The yacon fermentate showed an increase in acidity during one year (Table 1), which indicates a statistical difference during aging, which shows the influence of time on this constituent. Even with this increase due to time, in the end, the value found $(82.00 \mathrm{meq} / \mathrm{L})$ is within the values allowed by the Brazilian legislation (Brasil, 1988), whose ceiling is $130 \mathrm{meq} / \mathrm{L}$.

Other fermented fruit acidity values were lower than yacon, like fermented apple $60.22 \mathrm{meq} / \mathrm{L}$ (Satora et al., 2009) and cagaita (Oliveira et al., 2011) with $55.6 \mathrm{meq} / \mathrm{L}$.

The total acidity of the fermentate comprises two types of acidity, volatile and fixed. The first is removed during the distillation; acetic acid being the primary one. Since the second (fixed) refers to carboxylic acids, tartaric, citric, malic, lactic, succinic, capric, oxalic, fumaric, all responsible for the pH control (Soleas et al., 1997). Therefore, the overall acidity increase can be attributed to an increase in volatile or fixed acidity. Recamales et al. (2011) reported that during one year of aging there is an increase of some carboxylic acids such as capric acid.

The major component of volatile acidity is acetic acid. The conversion of ethanol to acetic acid is produced in the presence of oxygen, by means of acetic acid bacteria (Acetobacter aceti 
Acetobacter pasteurianus) that are undesirable in fermented products. Elevated amounts of such bacteria are regard as one of the major problems of fermentation (Bartowsky et al., 2003).

Acetic acid bacteria are considered aerobic (survive in environments where oxygen is available), but Drysdale \& Fleet (1989) demonstrated that these bacteria are found in fermented products, because they are able to survive in semi-anaerobic conditions and anaerobic (anaerobic with fractions of oxygen). During the aging of fermented yacon, volatile acidity was significantly influenced by increasing its content through of $6^{\text {th }}$ bimesters periods (Table 1 ). The final value was found to be $(3.3 \mathrm{mEq} / \mathrm{L})$ which is within the standards allowed by the Brazilian legislation of $20 \mathrm{mEq} / \mathrm{L}$. This demonstrates that oxygen was received, even with paraffin film wrapped on the top.

According to Brazilian law, for a fermented alcoholic to be considered soft, it must have a minimum amount of glucose (sugar lowering) of 20.1/L. After a year, the fermented of yacon presented a value of $34.7 \mathrm{~g} / \mathrm{L}$, which is regarded as a soft alcohol.

According to Rapp (1998), during the aging of wine, chemical changes occur, including the decrease and increase in esters of carboxylic acids and acetates and hydrolysis sugars. The latter is one of the changes that occurred throughout the aging process since there was a significant reduction of the reducing sugars. Lambri et al. (2012) stored white wine grapes originating from Chambave Muscat, for six months and found that there was also a decrease in reducing sugars at the end of that period. The sucrose content did not significantly differ following twelve months. This was most likely due to the presence of non-active yeasts which produce saccharifying enzymes responsible for hydrolyzing the sucrose. This remained constant throughout the storage period.

One of the most variable components in the fermentate is sulfur dioxide. It serves as an antiseptic and antioxidant, preventing the occurrence of undesirable bacteria, yeasts and enzymatic browning. The active part of the sulfur dioxide is what we call free sulfur dioxide. However, besides being a component toxic to humans, it is still responsible for some allergic effects and because of this the Brazilian legislation imposed a limit of $350 \mathrm{mg} / \mathrm{L}$ for fermented fruit (Rizzon \& Gatto, 1987; Brasil, 1988; Cejudo-Bastante et al., 2011).
At the end of the storage period, sulfur dioxide levels in the fermented yacon reached total levels of $(21.4 \mathrm{mg} / \mathrm{L})$, being within the parameters set by the law. Over time the level of free sulfur dioxide and total sulfur dioxide is significantly reduced. Godden et al. (2001) stored white wine grape Sémillo for 6 months to a year, and both groups showed a significant reduction in both the total and free sulfur dioxide content. After bottling, oxygen present in the space between the lid and the product reacted with the anhydride present in the fermentate. Theoretically, one mole of $\mathrm{O}_{2}$ reacts with two moles of $\mathrm{SO}_{2}$. Additionally, the reduction of $\mathrm{SO}_{2}$ can also occur through oxidation with phenolic compounds (Kwiatkowski et al., 2007).

The yacon stores fructooligosaccharides (FOS). FOS is in fact a sugar that is not digested by the human body because the body is unable to produce enzymes for hydrolyzing, giving them the classification as a dietary fiber or as soluble fiber (Valentová \& Ulrichová, 2003; Santana \& Cardoso, 2008).

By producing the fermented alcohol from yacon, it was expected that yeast, like humans, not would not hydrolyze the FOS, but this was not what was observed. Before starting the process of producing the fermented tuber, it was determined that its FOS content was $32 \%$. At the end of the fermentation process, and the beginning of the storage period, the content in the fermented was $0.46 \%$, showing that yeasts, unlike humans, were able to hydrolyze the FOS and use it by converting sucrose to ethanol. This was also confirmed by Hondo et al. (2000), when they performed their research using the yacon in the production of vinegar they also observed that at the beginning of fermentation of FOS the percentage was $7.2 \%$ and at the end of fermentation (10 days), the FOS amount dropped to $0.4 \%$, clearly indicating that these polysaccharide transforming yeast consumed alcohol.

Another great advantage in relation to food, is the content of phenolic compounds. Phenolic compounds are closely related to the ability to have bioactive anti-inflammatory and antioxidant activity, as has been shown previously in the prevention of the development of neurodegenerative diseases, cardiovascular diseases and cancer (Padilla et al., 2005; Kallithraka et al., 2009; Towantakavanit et al., 2011).

After a year of aging fermented yacon, it was found to have $223 \mathrm{mg} / \mathrm{L}$ of phenolic compounds, a considerable amount when

Table 1. Phisicochemical Analysis of one year aging.

\begin{tabular}{|c|c|c|c|c|c|c|}
\hline \multirow[b]{2}{*}{ Analysis } & \multicolumn{6}{|c|}{ Aging } \\
\hline & $1^{\text {st }}$ Bimester & $2^{\text {nd }}$ Bimester & $3^{\text {rd }}$ Bimester & $4^{\text {th }}$ Bimester & $5^{\text {th }}$ Bimester & $6^{\text {th }}$ Bimester \\
\hline Total acidity (meq/L) & $74.37 \pm 0.96^{\text {b* }}$ & $73.82 \pm 0.96^{\mathrm{b}}$ & $88.59 \pm 1.15^{\mathrm{a}}$ & $89.25 \pm 1.15^{\mathrm{a}}$ & $82.00 \pm 5.29^{\mathrm{a}}$ & $82.00 \pm 5.29^{\mathrm{a}}$ \\
\hline Volatile acidity (meq/L) & $0.18^{ \pm} 0.03^{\mathrm{b}}$ & $0.17 \pm 0.06^{\mathrm{b}}$ & $0.20 \pm 0.06^{\mathrm{b}}$ & $0.27 \pm 0.06^{\mathrm{b}}$ & $0.33 \pm 0.06^{\mathrm{a}}$ & $0.33 \pm 0.01^{\mathrm{a}}$ \\
\hline Ash $(g / L)$ & $2.39 \pm 0.03^{\mathrm{a}}$ & $2.22 \pm 0.10^{\mathrm{a}}$ & $2.27 \pm 0.07^{\mathrm{a}}$ & $2.15 \pm 0.03^{\mathrm{a}}$ & $2.24^{ \pm} 0.02^{\mathrm{a}}$ & $2.10 \pm 0.10^{\mathrm{a}}$ \\
\hline Reducing Sugars (g/L) & $36.60 \pm 0.05^{\mathrm{b}}$ & $35.80 \pm 0.03^{b}$ & $37.00 \pm 0.03^{\mathrm{a}}$ & $38.20 \pm 0.12^{\mathrm{a}}$ & $34.30 \pm 0.12^{c}$ & $34.70 \pm 0.01^{\mathrm{c}}$ \\
\hline sucrose $(\%)$ & $0.34 \pm 0.01^{\mathrm{a}}$ & $0.30 \pm 0.02^{\mathrm{a}}$ & $0.28 \pm 0.04^{\mathrm{a}}$ & $0.35 \pm 0.05^{\mathrm{a}}$ & $0.47 \pm 0.03^{\mathrm{a}}$ & $0.33^{ \pm} 0.05^{\mathrm{a}}$ \\
\hline Total sulfur dioxide $(\mathrm{mg} / \mathrm{L})$ & $28.87 \pm 0.80^{\mathrm{a}}$ & $26.4 \pm 0.34^{\mathrm{a}}$ & $25.87 \pm 0.92^{\mathrm{a}}$ & $21.12 \pm 0.44^{c}$ & $20.07 \pm 0.91^{c}$ & $21.43 \pm 0.53^{b}$ \\
\hline Free sulfur dioxide (mg/L) & $6.33 \pm 0.00^{\mathrm{a}}$ & $6.33 \pm 0.00^{\mathrm{a}}$ & $6.29 \pm 0.06^{\mathrm{a}}$ & $6.70 \pm 0.06^{\mathrm{a}}$ & $6.33 \pm 0.00^{\mathrm{a}}$ & $4.22 \pm 0.00^{\mathrm{b}}$ \\
\hline FOS $(\%)$ & $0.46 \pm 0.03^{\mathrm{a}}$ & $0.47 \pm 0.02^{\mathrm{a}}$ & $0.35 \pm 0.03^{\mathrm{b}}$ & $0.34 \pm 0.05^{\mathrm{b}}$ & $0.39 \pm 0.06^{\mathrm{b}}$ & $0.35 \pm 0.03^{\mathrm{b}}$ \\
\hline Phenolic Compounds(mg/L) & $195.00 \pm 0.51^{\mathrm{b}}$ & $198.90 \pm 0.59^{b}$ & $192.80 \pm 0.81^{\mathrm{b}}$ & $241.20 \pm 0.97^{\mathrm{a}}$ & $251.90 \pm 0.97^{\mathrm{a}}$ & $223.70 \pm 0.95^{\mathrm{a}}$ \\
\hline
\end{tabular}

*Values within the same row, followed by the same letter, are not significantly different $(\mathrm{p}<0.05)$. 
compared to white wines: $221 \mathrm{mg} /$ (Sanchez-Moreno, 2000), $515 \mathrm{mg} / \mathrm{L}$ (Satora et al., 2009), and $367 \mathrm{mg} / \mathrm{L}$ (Girard et al., 2001). The value found in this study, however, was much lower than that found for the fermentation of kiwi, $714 \mathrm{mg} / \mathrm{L}$ (Towantakavanit et al., 2011).

After one year of aging, the alcohol was verified to be $13 \%$ $\mathrm{v} / \mathrm{v}$ methanol values of $0.113(\mathrm{~g} / \mathrm{L})$ and antioxidant activity by the methods of DPPH and ABTS (Table 2).

Methanol or methyl alcohol, is of great concern, and is controlled by the Brazilian legislation. When ingested in amounts greater than $340 \mathrm{mg} / \mathrm{Kg}$, the body undergoes oxidation in the body, resulting in formaldehyde and formic acid, which are very toxic to the central nervous system. Some of the consequences when ingested in excessive amounts are dizziness, unconsciousness, respiratory arrest and cardiac (Soleas et al., 1997; Pereira \& Moretti, 1998; Cabaroglu, 2005).

The value at the end of storage for the fermentation of yacon $(0.113 \mathrm{~g} / \mathrm{L})$ is less than $0.35 \mathrm{~g} / \mathrm{L}$, which is allowed by Brazilian legislation (Brasil, 1988) and the tax limit $(0.15 \mathrm{mg} / \mathrm{L})$ by the International organization of grapes and wine (IOV). The value found in this study is similar to those found for white wines of $0.12 \mathrm{~g} / \mathrm{L}$ (Cabaroglu, 2005) and lower than that found in fermented apple (Satora et al., 2009) of $0.38 \mathrm{~g} / \mathrm{L}$ and Kiwi (Soufleros et al., 2001) of $0.48 \mathrm{~g} / \mathrm{L}$ while these are at the very top limit allowed by law.

The formation of methanol in alcoholic fermentation is produced by the action of pectinase enzymes on the pectins present in the feedstock. In this reaction, methyl groups are released as methanol, hence, the final content of this compound in the fermentation depends on the amount of pectin matter in the original material as does the degree of methylation (Soleas et al., 1997; Soufleros et al., 2001; Satora et al., 2009).

Another important factor and one of the most studied properties in relation to the consumption of alcoholic beverages is its antioxidant capacity. This is because in the human body the cause of various diseases are linked to the formation of free radicals, which, in turn, get "attacked" by antioxidants (Fernandes-Panchon et al., 2004; Kallithraka et al., 2009). The advantage of alcohol in relation to the content of antioxidants is in fact its bioavailability, as they are more soluble in ethanol than with water (main food component) (Soleas et al., 1997).

The main problem in the determination of these compounds is the fact that there is no standardized method. The methods

Table 2. Antioxidant activity and the content of fermented yacon methanol after one year of aging.

\begin{tabular}{lc}
\hline \multicolumn{1}{c}{ Analysis } & $\begin{array}{c}\text { After one year } \\
\text { of aging }^{*}\end{array}$ \\
\hline Antioxidant potential - ABTS (mmol Trolox/L) & $1.413 \pm 0.03^{\mathrm{a}}$ \\
Antioxidante potencial - DPPH (mmol trolox/L) & $1.605 \pm 0.04^{\mathrm{a}}$ \\
Methanol (g/L) & $0.113 \pm 0.00^{\mathrm{b}}$ \\
\hline
\end{tabular}

*Values within the same row, followed by the same letter, are not significantly different $(\mathrm{p}<0.05)$. used here are those of DPPH and ABTS, and the unit is in both trolox equivalent (TEAC) (Fernandes-Panchon et al., 2004).

The results found for both yacon fermented with ABTS (1,413 mM Trolox equivalent) and DPPH (1.605 mM Trolox equivalent) show an optimal antioxidant activity in comparison with the results for white wines, $0.84 \mathrm{mM}$ Trolox equivalent (DPPH) (Kallithraka et al., 2009) and $1.77 \mathrm{mM}$ trolox equivalent (ABTS) (Milardovic et al., 2007) and when compared to fermented apple of $0.46 \mathrm{mM}$ trolox equivalent (ABTS) (Satora et al., 2009).

\subsection{Sensory profile - Trained tasters}

According to Rapp (1998), the main stages of sensory analysis in fermented alcoholic beverages are the aroma and flavor. The aromatic part is formed by compounds originating in the raw material during the mechanical processes, fermentation and aging. The flavor portion is formed, mainly during fermentation to ethanol, glycerol, higher alcohols and organic acids.

Alcoholic fermentation is very complex, and there are many studies that have been conducted with the attempt to determine which compounds are responsible for each sensory characteristic, but so far there is no exact answer to this question (Sivertsen et al., 2001; Dooley et al., 2012).

For attributes of color, tannins and body, there were no significant differences observed between the fermented yacon (Table 3) and the two white wines. In relation to acidity, there was no difference between fermented yacon and the Sauvignon. The differences (Figure 1) were produced in the presence of attributes which were of greater complexity: such as the olfactory, gustatory and persistence qualities.

Dooley et al. (2012) conducted an analysis on white wines (Cabernet Sauvignon) with trained sensory panelists and achieved lower scores than those found in this study, with a persistence of 5.7, taste quality 5.94, 6.64 and olfactory quality.

The duration of aging is still somewhat uncertain due to the complexity of this product. Some researchers claim that at 10 months of aging, the fermentate begins to lose its aromatic components, mainly those which are responsible for the fruity aromas (Sivertsen et al., 2001; Recamales et al., 2011; Makhotkina et al., 2012). This may be one reason why the olfactory quality of the fermented yacon decreased compared to grape white wines. Even so, the alcoholic yacon fermentate was well accepted with regards to its descriptive attributes identified by testers trained when compared with wines already established on the market.

\subsection{Sensory acceptance - Untrained tasters}

Untrained tasters in sensory analysis performed acceptance testing (Table 4$)$ of fermented yacon and white wine $(11 \%$ smooth GL) found to be acceptable in the markets of the city of Goiânia, Brazil. As seen, the long duration of aging may have been detrimental to the characteristics of fermented yacon, 
Table 3. Mean scores of sensory attributes of fermented yacon aged for one year.

\begin{tabular}{|c|c|c|c|c|c|c|c|c|}
\hline Sample & Color & Acidity & Tannin & Body & $\begin{array}{l}\text { Olfactory } \\
\text { Quality }\end{array}$ & $\begin{array}{c}\text { Taste } \\
\text { Quality }\end{array}$ & $\begin{array}{c}\text { Complexity } \\
\text { Olfactory }\end{array}$ & Persistence \\
\hline Yacon & $5.00 \pm 0.0^{\mathrm{a} *}$ & $4.33 \pm 0.71^{\mathrm{a}}$ & $4.77 \pm 0.44^{\mathrm{a}}$ & $3.77 \pm 0.83^{\mathrm{a}}$ & $7.22 \pm 0.97^{\mathrm{a}}$ & $7.11 \pm 0.93^{\mathrm{a}}$ & $7.22 \pm 0.97^{\mathrm{a}}$ & $7.44 \pm 0.88^{\mathrm{a}}$ \\
\hline Sauvignon White & $5.00 \pm 0.0^{\mathrm{a}}$ & $4.77 \pm 0.0^{\mathrm{ab}}$ & $4.77 \pm 0.44^{\mathrm{a}}$ & $4.22 \pm 0.44^{\mathrm{a}}$ & $8.22 \pm 0.44^{\mathrm{b}}$ & $7.88 \pm 0.33^{\mathrm{b}}$ & $8.00 \pm 0.33^{\mathrm{b}}$ & $8.33 \pm 0.50^{\mathrm{b}}$ \\
\hline Chardonnay & $5.00 \pm 0.0^{\mathrm{a}}$ & $5.00 \pm 0.44^{\mathrm{b}}$ & $4.78 \pm 0.44^{\mathrm{a}}$ & $4.22 \pm 0.44^{\mathrm{a}}$ & $8.22 \pm 0.44^{\mathrm{b}}$ & $8.00 \pm 0.0^{\mathrm{b}}$ & $8.11 \pm 0.0^{\mathrm{b}}$ & $8.33 \pm 0.50^{\mathrm{b}}$ \\
\hline
\end{tabular}

${ }^{*}$ Values within a column, followed by the same letter, are not significantly $(\mathrm{p}<0,05)$.

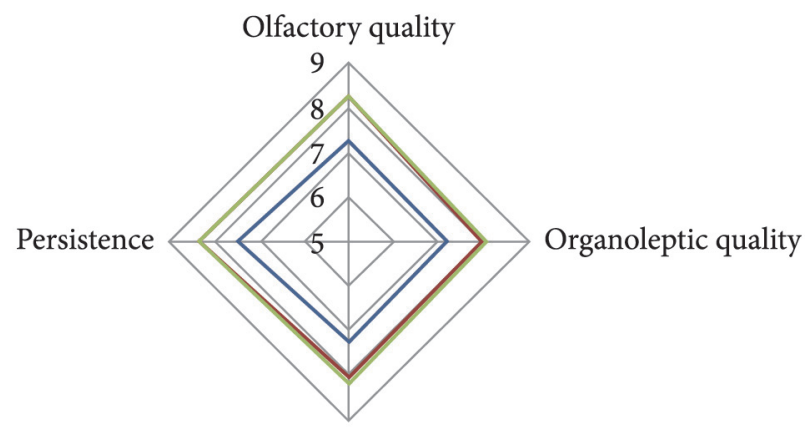

Olfactory complexity

— Yacon - Sauvignon white Chardonnay

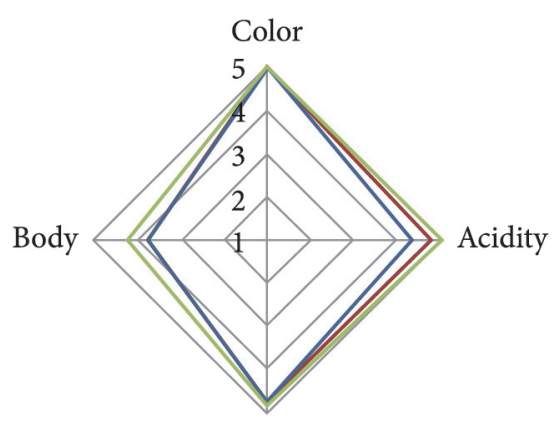

Tannis

— Yacon - Sauvignon white Chardonnay

Figure 1. Spider Graph - sensory attributes of fermented yacon alcohol after 1 year of aging.

causing loss of aromatics (Sivertsen et al., 2001; Recamales et al., 2011; Makhotkina et al., 2012).

Besides the duration of aging, different methods of processing the raw material for the production of fermented yacon may have also generated differences in olfactory evaluation (Losada et al., 2012). These may be some of the reasons which caused the attributes of odor to be significantly lower for fermented yacon (Table 4).

Gonzalez-Vinas et al. (1997) evaluated the aging of white wine at different stages and concluded that the aging time also decreases the overall impression, as was observed in the fermented yacon. The results described above, along with supporting work from other authors, we are able to come to some important conclusions.
Table 4. Mean scores for sensory attributes given by untrained tasters to fermented alcoholic yacon after one year of aging.

\begin{tabular}{lcccc}
\hline & Appearance & Odor & Flavor & Global \\
\hline Yacon & $6.77 \pm 1.36^{\mathrm{a} *}$ & $5.82 \pm 1.88^{\mathrm{b}}$ & $5.49 \pm 1.95^{\mathrm{b}}$ & $5.91 \pm 1.67^{\mathrm{b}}$ \\
$\begin{array}{l}\text { Commercial } \\
\text { Soft White Wine }\end{array}$ & $6.83 \pm 1.36^{\mathrm{a}}$ & $7.10 \pm 1.62^{\mathrm{a}}$ & $6.81 \pm 1.59^{\mathrm{a}}$ & $6.82 \pm 1.37^{\mathrm{a}}$ \\
\hline *Values within a column, followed by the same letter, are not significantly $(\mathrm{p}<0,05)$.
\end{tabular}

\section{Discussion}

About the chemical characteristics, the acidity is one of the most important one, the differences between the levels of acidity in fermented fruits are attributed to different processing methods, time of year, and the characteristics of the raw material (Holt et al., 2008; Gómez García-Carpintero et al., 2012). Acidity is an extremely important parameter, but also directly involved in the sensory properties of fermentation. According to Soufleros et al. (2001) and Cliff et al. (2007), it was demonstrated that the greater the degree of maturity of the raw material used, the lower the acidity of the alcohol fermented.

About the volatile acidity, the increase presented on this study can be explain by Bartowsky et al. (2003) and Mas et al. (2002), that demonstrated that conducting the aging process with bottles placed vertically using screw caps and rubber closures, allowed higher oxygen input and thus a higher content of volatile acidity. In this study, despite having been aged in a horizontal position, the bottles was closed with screw cap, sealed with parafilm and maybe that is the reason for higher oxygen input and significant increase in volatile acidity.

The sulfur dioxide when is in excess, is toxic to humans, and it can react with acetaldehyde in the fermented, resulting in an undesirable residual flavor in the product (Satora et al., 2009). Over time the level of free sulfur dioxide and total sulfur dioxide was significantly reduced, showing the ability to protect the product.

The content of fructooligosaccharides was not expected to decrease, but according to Rapp (1998), after the fermented is bottled, remaining simple sugars can undergo hydrolysis or form complexes. Monagas et al. (2006) also argue that, even after the filtering process, the fermentation may have "residual micro-organisms" that can convert sugar into alcohol. These are some hypotheses that may explain the reasons why there is a significant decrease FOS throughout the storage period.

During the entire period of storage of fermented yacon, a significant increase in phenolic compounds was observed, as was observed in red wine stored for a year and a half, studied by Monagas et al. (2006). This may be due to a gradual 
and constant increase of solubility of these compounds in ethanol (Baiano et al., 2009; Towantakavanit et al., 2011) or because these compounds have many components that each react differently during storage, the final content of phenolic compounds depends on the composition thereof as (caffeic acid, ferulic acid and coumaric) which increases with storage time (Kallithraka et al., 2009).

After one year of chemical analysis a sensory study was realized. There are still other difficulties in the sensory evaluation of the product, as its aromatic characteristics vary according to the climate, the soil, the yeast used, the temperature of fermentation and aging method. Moreover, there is no sensory profile of consumers. This is because there is a big difference between the "experts" in sensory analysis and consumers who both frequently and infrequently ingest fermented products (Rapp, 1998; Recamales et al., 2011; Dooley et al., 2012).

On the sensory study with the trained tasters and with the untrained tasters, the fermented of yacon had lower values than the commercial ones. Factors that may have been attributed to significantly lower values when compared to white wines are, time and position of the bottle during aging, type of yeast and raw materials used and the processing method (Wu et al., 2011; Oliveira et al., 2011; Losada et al., 2012). Meillon et al. (2009), argued that the persistence of a fermented is linked to its complexity and ethanol content, therefore, this difference was also a sensory feature of the fermented yacon. Possible that one of the main factores of influence for flavor was ethanol content, or its alcohol content. Ethanol reduces the evaporation of volatile compounds, therefore generating different amounts of different sensations of aromatic alcohol (Soleas et al., 1997).

In addition, up $12.5 \%$ alcohol levels, the taste may be compromised by the high alcohol content (Soufleros et al., 2001; Towantakavanit et al., 2011). This may be the reason that the fermented yacon had significantly lower flavor attributes, once the alcohol content was $13 \%$. Another possible explanation for the observed differences in this sensory study was the screw caps used in the bottles sealed during aging. This type of cover diminished the persistence and decreased the sensory quality of the fermented (Lopes et al., 2006).

After all, the alcohol from fermented of yacon is chemically stable, maintaining total acidity, sulfur dioxide and volatility, within the limits of the law Brazilian throughout aging. It also showed considerable antioxidant potential, a low methanol content and was accepted among trained and untrained tasters.

Throughout the processing parameters describes, this paper shows through control of aging and certain chemical parameters, the aging time of one year is excessive and has been attributed to the loss of aromatic compounds. From this study, it can be determined that with shorter times of aging, one can minimize these quality losses.

\section{References}

Baiano, A., Terracone, C., Gambacorta, G., \& Lanotte, A. (2009). Phenolic Content and Antioxidant Activity of Primitivo Wine: Comparison among Winemaking Technologies. Food chemistry, 74(3), 258-267.
Bartowsky, E. J., Xia, D., Gibson, R. L., Fleet, G. H., \& Henschke, P. A. (2003). Spoilage of bottled red wine by acetic acid bacteria. Letters in Applied Microbiology, 36(5), 307-314. http://dx.doi.org/10.1046/ j.1472-765X.2003.01314.x

Brand-Willians, W., Cuvelier, M. E., \& Berset, C. (1995). Use of a free radical method to evaluate antioxidant activity. Food science and Technology, 28(1), 25-30.

Brasil, Ministerio da Agricultura e do Abastecimento (1988). Portaria $\mathrm{n}^{\circ} 229$. Brasília.

Cabaroglu, T. (2005). Methanol contents of Turkish varietal wines and effect of processing. Food Control, 16(2), 177-181. http://dx.doi. org/10.1016/j.foodcont.2004.01.008

Cejudo-Bastante, M. J., Pérez-Coello, M. S., \& Hermosín-Gutiérrez, I. (2011). Effect of wine micro-oxygenation treatment and storage period on colour-related phenolics, volatile composition and sensory characteristics. Food Science and Technology, 44(4), 866-874.

Cliff, M. A., King, M. C., \& Schlosser, J. (2007). Anthocyanin, phenolic composition, colour measurement and sensory analysis of BC commercial red wines. Food Research International, 40(1), 92-100. http://dx.doi.org/10.1016/j.foodres.2006.08.002

Diäaz-Maroto, M. C., Chneider, R., \& Baumes, R. (2005). Formation Pathways of Ethyl Esters of Branched Short-Chain Fatty Acids during Wine Aging. Journal of Agricultural food and chemistry, 53(9), 3503-3509. PMid:15853394. http://dx.doi.org/10.1021/jf048157o

Dias, D. R., Schwan, R. F., Freire, E. S., \& Serôdio, R. D. S. (2007). Elaboration of a fruit wine from cocoa (Theobroma cacao L.) pulp. International Journal of Food Science \& Technology, 42(5), 319-329. http://dx.doi.org/10.1111/j.1365-2621.2006.01226.x

Dooley, L., ThrelfalL, R. T., \& Meullenet, J. F. (2012). Optimization of blended wine quality through maximization of consumer liking. Food Quality and Preference, 24(1), 40-4. http://dx.doi.org/10.1016/j. foodqual.2011.08.010

Drysdale, G. S., \& Fleet, G. H. (1989). The growth and survival of acetic acid bacteria in wines at different concentrations of oxygen. American Journal of Enology and Viticulture, 40(2), 99-105.

Duarte, W. F., Dias, D. R., Oliveira, J. M., Teixeira, J. A., Silva, J. B. A., \& Schwan, R. F. (2010). Characterization of different fruit wines made from cacao, cupuassu, gabiroba, jabuticaba and umbu. LWT Food Science and Technology, 43(10), 1564-1572. http://dx.doi. org/10.1016/j.lwt.2010.03.010

Duarte, W. F., Dias, D. R., Pereira, G. V. M., Gervásio, I. M., \& Schwan, R. F. (2009). Indigenous and inoculated yeast fermentation of gabiroba (Campomanesia pubescens) pulp for fruit wine production. Journal of Industrial Microbiology \& Biotechnology, 36, 557-569. PMid:19190949. http://dx.doi.org/10.1007/s10295-009-0526-y

Fanzone, M., Zamora, F., Jofré, V., Assof, M., Gómez-Cordovés, C., \& Peña-Neira, A. (2012). Phenolic characterisation of red wines from different grape varieties cultivated in Mendoza province (Argentina). Journal of the Science of Food and Agriculture, 92(3), 704-718. PMid:21919008. http://dx.doi.org/10.1002/jsfa.4638

Fernandes-Panchon, M., Villano, D., Troncoso, A. M., \& GarciaParrilla, M. C. (2004). Antioxidant Activity of Phenolic Compounds: From In Vitro Results to In Vivo Evidence. Food Science and Nutrition, 48(7), 649-671.

Girard, B., Yuksel, D., Cliff, M. A., Delaquis, P., \& Reynolds, A. G. (2001). Vinification effects on the sensory, colour and GC profiles of Pinot noir wines from British Columbia. Food Research International, 34(6), 483-499. http://dx.doi.org/10.1016/S0963-9969(00)00177-0

Godden, P., Francis, L., Field, J., Gishen, M., Coulter, A., Valente, P., Hoj, P., \& Robinson, E. (2001). Wine bottle closures: Physical 
characteristics and effect on composition and sensory properties of a Semillion wine. Performance up to 20 months post-bottling. Australian Journal of Grape and Wine, 7(2), 62-105. http://dx.doi. org/10.1111/j.1755-0238.2001.tb00195.x

Gómez García-Carpintero, E., Gómez Gallego, M. A., Sánchez-Palomo, E., \& González Viñas, M. (2012). Impact of alternative technique to ageing using oak chips in alcoholic or in malolactic fermentation on volatile and sensory composition of red wines. Food chemistry, 134(2), 851-63. PMid:23107700. http://dx.doi.org/10.1016/j. foodchem.2012.02.194

Gonzalez-Vinas, M. A., Perez-Coello, M. S., \& Cabezudo, M. D. (1997). Sensory analysis of aroma attributes of young white wines during storage in the bottle. Journal of Food Quality, 21(3), 285-297.

Holt, H. E., Francis, I. L., Field, J., Herderich, M. J., \& Iland, P. G. (2008). Relationships between wine phenolic composition and wine sensory properties for Cabernet Sauvignon (Vitis vinifera L.). Australian Journal of Grape and Wine Research, 14(2), 162-176.

Hondo, M., Okumura, Y., \& Yamak, T. A. (2000). Preparation Method of Yacon Vinegar Containing Natural Fructooligosaccharides. Nippon Shokuhin Kagaku Kogaku Kaishi, 47(10), 803-807. http://dx.doi. org/10.3136/nskkk.47.803

International Organization for Standardization. (1997). ISO 3591: Sensory analysis - Wine tasting glass. ISO.

International Organization for Standardization. (1998). ISO 8589: Design of Test Rooms for Sensory Analysis of Food. ISO.

Jermyn, M. A. (1956). A new method for the determination of ketohexoses in presence of aldohexoses. Nature, 177, 38-39. http:// dx.doi.org/10.1038/177038a0

Kallithraka, S., Salacha, M. I., \& Tzourou, I. (2009). Changes in phenolic composition and antioxidant activity of white wine during bottle storage: Accelerated browning test versus bottle storage. Food Chemistry, 113(2), 500-505. http://dx.doi.org/10.1016/j. foodchem.2008.07.083

Kwiatkowski, M. J., Skouroumounis, J. K., Lattey, K. A., \& Waters, E. J. (2007). The impact of closures, including screw cap with three different headspace volumes, on the composition, colour and sensory properties of a Cabernet Sauvignon wine during two years' storage. Australian Journal of Grape and Wine Research, 13(2), 81-94. http://dx.doi.org/10.1111/j.1755-0238.2007.tb00238.x

Lambri, M., Dordoni, R., Silva, A., \& De Faveri, D. (2012). Comparing the impact of bentonite addition for both must clarification and wine fining on the chemical profile of wine from Chambave Muscat grapes. International Journal of Food Science and Technology, 47(1), 1-12. http://dx.doi.org/10.1111/j.1365-2621.2011.02800.x

Latimer, G. W. (2006). Official Methods of Analysis of the Association of Official Analytical Chemistry. 18th ed. Washington: AOAC.

Lopes, P., Saucier, C., Teissedre, P., \& Glories, Y. (2006). Impact of Storage Position on Oxygen Ingress through Different Closures into Wine Bottles. Journal of Agricultural food and chemistry, 54(18), 6741-6746. PMid:16939334. http://dx.doi.org/10.1021/jf0614239

Losada, M. M., Lopez, J. F., Andres, J., \& Revilla, E. (2012). Influence of some oenological practices on the aromatic and sensorial characteristics of white Verdejo wines. International Journal of Food Science and Technology, 47(9), 1826-1834. http://dx.doi. org/10.1111/j.1365-2621.2012.03038.x

Makhotkina, O., Pineau, B., \& Kilmartin, P. A. (2012). Effect of storage temperature on the chemical composition and sensory profile of Sauvignon Blanc wines. Australian Journal of Grape and Wine Research, 18(2), 91-99. http://dx.doi.org/10.1111/j.17550238.2011.00175.x
Mas, A., Puig, J., Lladó, N., \& Zamora, F. (2002). Sealing and Storage Position Effects on Wine Evolution. Journal of food science, 67, 1374- 1378. http://dx.doi.org/10.1111/j.1365-2621.2002.tb10292.x

Meillon, S., Urbano, C., \& Schlich, P. (2009). Contribution of the Temporal Dominance of Sensations (TDS) method to the sensory description of subtle differences in partially dealcoholized red wines. Food Quality and Preference, 20(6), 490-499. http://dx.doi. org/10.1016/j.foodqual.2009.04.006

Milardovic, S., Kerekovic, I., \& Rumenjak, V. (2007). A flow injection biamperometric method for determination of total antioxidant capacity of alcoholic beverages using bienzymatically produced ABTS. Food Chemistry, 105(4), 1688-1694. http://dx.doi. org/10.1016/j.foodchem.2007.04.056

Miller, G. L. (1959). Use of dinitrosalicylic acid reagent for determination of reducing sugar. Analytical Chemistry, 31, 426-428. http://dx.doi.org/10.1021/ac60147a030

Monagas, M., Gomez-Cordoves, C., \& Bartolomé, B. (2006). Evolution of the phenolic content of red wines from Vitis vinifera L. during ageing in bottle. Food Chemistry, 95(3), 405-412. http://dx.doi. org/10.1016/j.foodchem.2005.01.004

Ojansivu, I., Ferreira, C., \& Salminen, S. (2011). Yacon, a new source of prebiotic oligosaccharides with a history of safe use. Trends in Food Science \& Technology, 22(1), 40-46. http://dx.doi.org/10.1016/j. tifs.2010.11.005

Oliveira, M. E. S., Pantoja, L., Duarte, W. F., Collela, C. F., Valarelli, L. T., Schwan, R. F., \& Dias, D. R. (2011). Fruit wine produced from cagaita (Eugenia dysenterica DC) by both free and immobilised yeast cell fermentation. Food Research International, 44(7), 2391-2400. http://dx.doi.org/10.1016/j.foodres.2011.02.028

Padilla, E., Ruiz, E., Redondo, S., Gordillo-Moscoso, A., Slowing, K, \& Tejerina, T. (2005). Relationship between vasodilation capacity and phenolic content of Spanish wines. European Journal of Pharmacology, 517(2), 84-91. PMid:15967426. http://dx.doi. org/10.1016/j.ejphar.2005.04.044

Pereira, I. M., \& Moretti, R. H. (1998). Caracterizasao fisica, quimica e sensorial do vinho branco se sauvignon blanc tratado com polivinilpolipilTolidona(PVPP). Ciência e Tecnologia de Alimentos, 17(2), 192-195. http://dx.doi.org/10.1590/S010120611997000200024

Rapp, A. (1998). Volatile flavour of wine: Correlation between instrumental analysis and sensory perception. Nahrung/ Food, 42, 351-363. http://dx.doi.org/10.1002/(SICI)15213803(199812)42:06<351::AID-FOOD351>3.3.CO;2-U

Recamales, A. F., Gallo, V., Hernanz, D., González-Miret, M. L., \& Heredia, F. J. (2011). Effect of Time and Storage Conditions on Major Volatile Compounds of Zalema White Wine. Journal of Food Quality, 34(2), 100-110. http://dx.doi.org/10.1111/j.1745-4557.2011.00371.x

Rizzon, L. A., \& Gatto, N. M. (1987). Caracte-risticas analiticas dos vinhos da microrre-giao homogenea vinicultora de Caxias do sul :MRH 311: analises classicas (Comunicado Tecnico, n. 5). Bento Gonyalves: Embrapa.

Rizzon, L. A., \& Miele, A. (2003). Avaliação da cv.cabernet sauvignon para elaboração de vinho tinto. Ciência e Tecnologia de Alimentos, 22(2), 192-198. http://dx.doi.org/10.1590/S010120612002000200015

Rufino, M. S., Alves, R. E., Brito, E. S., Morais, S. M., Sampaio, C. G., Pérez-Jiménez, J., \& Saura-Calixto, F. D. (2007). Metodologia Científica: Determinação da Atividade Antioxidante Total em Frutas pela Captura do Radical Livre ABTS (Comunicado Técnico Embrapa n. 128). Embrapa. 
Sanchez-Moreno, C. (2000). Methods used to evaluate the free radical scavenging activity in foods and biological systems. Food Science \& Technology International, 8(3), 121-137. http://dx.doi. org/10.1177/1082013202008003770

Santana, I., \& Cardoso, M. H. (2008). Raiz tuberosa de yacon (Smallanthus Sonchifolius), potencialidade de cultivo, aspectos tecnológicos e nutricionais. Ciência Rural, 38(3), 898-905. http:// dx.doi.org/10.1590/S0103-84782008000300050

Satora, P., Tarko, T., Duda-Chodak, D., Sroka, P., Tuszynski, T., \& Czepielik, M. (2009). Influence of Prefermentative Treatments and Fermentation on the Antioxidant and Volatile Profiles of Apple Wines. Journal of Agriculture and Food Chemistry, 57(23), 1120911217. PMid:19911770. http://dx.doi.org/10.1021/jf9025053

Sivertsen, H. K., Figenschou, E., Nicolaysen, F., \& Risvik, E. (2001). Sensory and chemical changes in Chilean Cabernet Sauvignon wines during storage in bottles at different temperatures. Journal of the Science of Food and Agriculture, 81(15), 1561-1572. http:// dx.doi.org/10.1002/jsfa.971

Soleas, G. J., Diamandis, E. P., \& Goldberg, D. M. (1997). Wine as a Biological Fluid : History, Production, and Role in Disease Prevention. Journal of Clinical Laboratory Analysis, 11(5), 287-313. http://dx.doi.org/10.1002/(SICI)1098-2825(1997)11:5<287::AIDJCLA6>3.0.CO;2-4
Soufleros, E. H., Pissa, I., Petridis, D., Lygerakis, M., Mermelas, K., Boukouvalasb, G., \& Tsimitakis, E. (2001). Instrumental analysis of volatile and other compounds of Greek kiwi wine; sensory evaluation and optimisation of its composition. Food Chemistry, 75(4), 487-500. http://dx.doi.org/10.1016/S0308-8146(01)00207-2

Towantakavanit, K., Park, Y. S., \& Gorinstein, S. (2011). Quality properties of wine from Korean kiwifruit new cultivars. Food Research International, 44(5), 1364-1372. http://dx.doi.org/10.1016/j. foodres.2011.01.028

Valentová, K., \& Ulrichová, J. (2003). Smallanthus sonchifolius and Lepidium meyenii - prospective Andean crops for the prevention of chronic diseases. Biomedical Papers, 147(2), 119-130. http://dx.doi. org/10.5507/bp.2003.017

Wu, Y., Zhu, B., Tu, C., Duan, C., \& Pan, Q. (2011). Generation of Volatile Compounds in Litchi Wine during Winemaking and ShortTerm Bottle Storage. Journal of Agricultural food and chemistry, 59(9), 4923-4931. PMid:21456617. http://dx.doi.org/10.1021/ jf2001876

Zieliski, H., \& Kozowska, H. (2000). Antioxidant activity and total phenolics in selescted cereal graims and their different morphological fractions. Journal of Agricultural and Food Chemistry, 48(6), 2008-2016. http://dx.doi.org/10.1021/jf990619o 